\title{
RAPORT
}

„Studia Wyborcze”, tom 28, 2019

DOI: https://doi.org/10.26485/SW/2019/28/6

\section{RAPORT Z MISJI OBSERWACYJNEJ PRZEDTERMINOWYCH WYBORÓW PARLAMENTARNYCH NA UKRAINIE W 2019 ROKU PEŁNIONEJ Z RAMIENIA ORGANIZACJI BEZPIECZEŃSTWA I WSPÓKPRACY W EUROPIE W OBWODZIE MIKOKAJOWSKIM ${ }^{1}$}

Dedykuję czlonkom komisji wyborczych, których zaangażowanie, ciężka praca $i$ wytrwałość w obliczu wielu przeciwności doprowadzity do przeprowadzenia wyborów, ich postawa daje nadzieję na dalszy rozwój społeczeństwa obywatelskiego Ukrainy.

Autor

WYKAZ SKRÓTÓW

AoR - Area of Responsibility - teren (w tym wypadku obwód mikołajowski), który został wyznaczony LTO przez CT do obserwacji

BPP - Blok Petra Poroszenki

CEC - Central Election Commission - Centralna Komisja Wyborcza

CT - Core Team - sztab misji OBWE/ODIHR

DEC - District Election Commission - jednomandatowy okręg wyborczy bądź komisja jednomandatowego okręgu wyborczego, bądź lokal jednomandatowego okręgu wyborczego

LTO - Long Term Observers - dwuosobowy zespół obserwatorów długoterminowych OBWE/ODIHR

OP - Blok Opozycyjny

OPZŻ - Opozycyjna Platforma za Życie

PEC - Precinct Election Commissions - obwód wyborczy bądź komisja obwodu wyborczego, bądź lokal okręgu wyborczego

\footnotetext{
${ }^{1}$ Publikowany tekst jest subiektywnym obrazem wybranych elementów procesu wyborczego przedterminowych wyborów parlamentarnych zaobserwowanych w obwodzie mikołajowskim przez autora i nie jest oficjalnym stanowiskiem OBWE ani Ministerstwa Spraw Zagranicznych RP.
} 
SMC - Single Mandate Candidate - kandydat startujący w wyborach parlamentarnych z jednomandatowego okręgu wyborczego

STO - Short Term Observers - dwuosobowy zespół obserwatorów krótkoterminowych OBWE/ODIHR

WR - Werchowna Rada Ukrainy - najwyższa (i jedyna) izba ukraińskiego parlamentu

\section{TYTUŁEM WSTĘPU}

Raport jest podsumowaniem pracy długoterminowych obserwatorów - Jakuba Herolda (Polska) oraz Sussane Cooper (Stany Zjednoczone), którzy stanowiąc dwuosobowy zespół LTO 26 (byli odpowiedzialni za obserwację przedterminowych wyborów parlamentarnych na Ukrainie z ramienia Organizacji Bezpieczeństwa i Współpracy w Europie. Terenem obserwacji - AoR, którą wyznaczono LTO 26 był obwód mikołajowski (południowa Ukraina). Obszar AoR był podzielony na sześć DEC z blisko milionem potencjalnych wyborców. Do realizacji swoich obowiązków LTO 26 zaangażował miejscowych mieszkańców - Wladlenę Bugaj (asystentka) oraz Oleksandra Worontsowa (kierowca). Okres pełnienia misji (16.06.- 31.07.) składał się z trzech etapów obserwacji: przedwyborczego, dnia wyborów i powyborczego. Dotyczył monitoringu m.in. takich elementów procesu wyborczego jak: kampania wyborcza, rejestracja kandydatów i wyborców, media, administracja wyborcza, postawa lokalnych decydentów, bezpieczeństwo obwodu. W powyższym celu LTO 26 zrealizował kilkadziesiąt spotkań, aby przeprowadzić wywiady z kluczowymi postaciami mającymi związek z wyborami i odbył wiele podróży służbowych w granicach AoR (łącznie $2141 \mathrm{~km}$ ).

Osobnym wyzwaniem było przygotowanie przyjazdu oraz koordynowanie obserwacji 20 STO, które spędziły w AoR cztery kluczowe dni procesu wyborczego (19-22.07.). Nad działaniami wszystkich (łącznie 48) zespołów LTO na Ukrainie rozsianych na terytorium całego kraju (z wyjątkiem części okupowanej przez separatystów i Rosjan oraz Krymu) czuwał Core Team zlokalizowany w Kijowie, w którego skład wchodziło kilkunastu specjalistów z krajów członkowskich OBWE. Głównym zadaniem LTO było relacjonowanie za pomocą pisemnych raportów $\mathrm{z}$ sytuacji związanej $\mathrm{z}$ wyborami $\mathrm{w}$ ich AoR. Do tej misji Fundacja Solidarności Międzynarodowej delegowała czworo obserwatorów: Sławomira Szyszkę, Paulinę Czarnecką, Jarosława Derlickiego i Jakuba Herolda. 


\section{KULISY PRZEDTERMINOWYCH WYBORÓW PARLAMENTARNYCH NA UKRAINIE}

21 lipca 2019 roku odbyły się przedterminowe wybory parlamentarne do Werchownej Rady Ukrainy. To była dziewiąta edycja wyborów do ukraińskiego parlamentu od 1990 roku. Należy zaznaczyć, że to drugie z rzędu, a czwarte w ogóle przedterminowe wybory u wschodniego sąsiada Polski. Wybory parlamentarne w 2014 roku były wynikiem kolejno: Rewolucji Godności, rozpadu rządu Mykoły Azarowa i jego ucieczki do Rosji z ówczesnym prezydentem Wiktorem Janukowyczem, wojną z prorosyjskimi separatystami i Rosją w Donbasie, zajęciem przez Rosję Krymu i przedterminowymi wyborami prezydenckimi, w których zwyciężył w pierwszej turze Petro Poroszenko. W tym roku inicjatorem zakończenia obecnej VIII kadencji ukraińskiego parlamentu i rozpisania przedterminowych wyborów parlamentarnych był nowo wybrany prezydent Ukrainy Wołodymyr Zełenski, który motywował ten krok zanikiem koalicji parlamentarnej. Mimo że po legislacyjnych przepychankach Sąd Konstytucyjny ostatecznie usankcjonował tę decyzję, ukraińska opinia publiczna nie miała wątpliwości, że prawdziwą przyczyną przyspieszenia (o trzy miesiące) daty wyborów była chęć Zełenskiego zdyskontowania wielkiego zaufania społecznego, które przełożyło się na $73 \%$ poparcia dla niego w II turze wyborów prezydenckich. Na powszechną akceptację tej decyzji wpłynęły również tradycyjne już skandale korupcyjne nad Dnieprem ludzi związanych z Petrem Poroszenką. Społeczeństwo ukraińskie od dłuższego czasu wykazywało zniechęcenie brakiem rozwiązań w kwestiach: zamrożonego konfliktu w Donbasie, sytuacji związanej z okupacją Krymu, brakiem sukcesów w uwolnieniu ukraińskich jeńców wojennych, czy raptownym wzrostem taryf komunalnych, choć trzeba zaznaczyć, że tylko niewielka część tych wyzwań należy wyłączenie do decyzyjności kierownictwa Ukrainy. O kryzysie politycznym (permanentny stan na Ukrainie) i niewielkim poparciu społecznym świadczy fakt, że na liście 22 partii startujących w wielomandatowym okręgu wyborczym nie znalazła się partia Front Narodowy, która zajęła drugie miejsce w poprzednich wyborach w 2014 roku i wspólnie z BPP stworzyła rząd.

\section{SYTUACJA POLITYCZNA W OBWODZIE MIKOŁAJOWSKIM W PRZEDEDNIU WYBORÓW}

Do wyborów prezydenckich (kwiecień 2019) najważniejszą postacią w obwodzie mikołajowskim był gubernator Aleksiej Sawczenko. Do momentu nominacji na to stanowisko przez prezydenta Ukrainy Petra Poroszenkę był ban- 
kierem, a następnie politykiem. Wcześniej służył w kijowskiej policji w randze oficera. Na szczeblu centralnym mógł liczyć na wsparcie Walerija Heleteja (byłego szefa ukraińskiego odpowiednika Służby Ochrony Polski), a zatem osoby bliskiej byłemu prezydentowi. W czasie pełnienia przez Sawczenkę stanowiska gubernatora (zrezygnował po przegranej Poroszenki w wyborach prezydenckich) Rada Obwodu Mikołajowskiego zdominowała Radę Miasta Mikołajowa i jej przewodniczącego (mera) Ołeksandra Senkewycza. W wyniku wewnętrznych walk w Radzie Miasta i braku wsparcia własnej partii (Samopomoc) Senkewycz został odwołany ze stanowiska, żeby ostatecznie powrócić na nie, po upewnieniu się przez Sawczenkę, że będzie wobec niego lojalny. Podczas spotkania z LTO 26 Senkewycz powiedział, że dzisiaj nie ma konfliktu między radami miasta i obwodu (co często podkreślali rozmówcy) i istnieje rotacja urzędników między tymi dwoma organami. Obecnie pełniącym obowiązki gubernatora regionu jest Wiaczesław Boń, który nie jest oceniany jako aktywny gracz polityczny.

Obwód mikołajowski jest także areną działalności oligarchy Aleksieja Wadaturskiego - szefa konsorcjum Nibulon. Jego syn - Andrij Wadaturski był posłem z ramienia Bloku Petra Poroszenkii startował jako kandydat niezależny z DEC 130 (Basztanka). Siedziba Nibulonu znajduje się w Mikołajowie. Przedsiębiorstwo zajmuje się produkcją, magazynowaniem i transportem zboża, a do tego posiada własną flotę statków, stocznie i terminal przeładunkowy w Mikołajowie. Aleksiej Wadaturski ma znaczący wpływ na sytuację gospodarczą w obwodzie mikołajowskim, a jego działania, takie jak ożywienie rzecznego transportu pasażerskiego na Południowym Bugu lub uzyskanie od władz Kijowa zezwolenia na pogłębienie koryta rzeki zwiększa atrakcyjność inwestycyjną regionu. Działalność Nibulonu wpływa nie tylko na rozwój samego Mikołajowa, ale także na mniejsze ośrodki miejskie, takie jak Woznesensk i Nowa Odessa.

Sytuacja polityczna podczas obserwacji LTO 26 rozwijała się dość dynamicznie, ponieważ nie było jasne kogo prezydent mianuje gubernatorem obwodu. Jednym z kluczowych pytań pozostawała współpraca Rady Obwodu z Radą Miasta Mikołajowa lub jej brak w przyszłości. Napięcie potęgował fakt, że w powszechnej opinii występowało wysokie prawdopodobieństwo rozpisania wyborów samorządowych w tym roku (2019), co jeszcze bardziej przemebluje scenę polityczną obwodu. Warto podkreślić, że w czasie wizyty Wołodymyra Zełenskiego w Mikołajowie (17.07.) na lotnisku podczas emocjonalnej rozmowy z Wiaczesławem Boniem, w obecności dziennikarzy, ten ostatni obiecał prezydentowi podpisanie rezygnacji ze stanowiska, z czym później zwlekał miesiąc. Co ciekawe, mer Mikołajowa nie spotkał się z prezydentem ponieważ... był na urlopie, co Zełenski publicznie ocenił jako tchórzostwo. Później Senkewycz tłumaczył to brakiem możliwości spotkania 
z Zełenskim, gdyż ten miał w planie wizyty wyłącznie w obiektach państwowych, a nie miejskich.

Ta be la 1. Polityczny układ sił w obwodzie mikołajowskim

\begin{tabular}{|c|c|}
\hline p.o. Gubernatora & Wiaczesław Boń, nominowany 06.10.2016 \\
\hline $\begin{array}{c}\text { Przewodniczący Rady } \\
\text { Obwodu Mikołajowskiego }\end{array}$ & Wiktoria Moskalenko (Blok Petra Poroszenko - Solidarność \\
(BPP)
\end{tabular}

Źródło: opracowanie własne.

\section{KAMPANIA WYBORCZA W OBWODZIE MIKOŁAJOWSKIM}

W przedterminowych wyborach $\mathrm{w}$ wielomandatowym okręgu wyborczym wystartowały 22 partie polityczne. W obwodzie mikołajowskim w sześciu jednomandatowych okręgach wyborczych ostatecznie zarejestrowano 88 SMC, z których 38 było kandydatami niezależnymi, a 50 nominowały ugrupownaia polityczne.

Z godnie z ustawą Pro narodnych deputatiw Ukrainy - SMC mogą rozpoczać kampanię wyborczą wyłącznie po uprzedniej rejestracji swojej kandydatury w Centralnej Kommisji Wyborczej - CEC (Central Election Comission), a wszystkie wydatki związane z kampanią muszą przechodzić przez specjalnie stworzone do tego celu konto bankowe ${ }^{2}$. Początek kampanii w AoR LTO 26 można uznać za stosunkowo ospały. SMC ograniczyli się prawie wyłącznie do aktywizacji swojego stałego elektoratu. Skutkowało to m.in. problemem w ustaleniu przez LTO 26 informacji o planowanych spotkaniach SMC z wyborcami czy nawet lokalizacją ich sztabów wyborczych.

Można wysnuć tezę, że obecność w kampanii wyborczej świeżego projektu politycznego - Sługa Ludu znacznie zdynamizował jej późniejszy przebieg i wymógł większą aktywność na pozostałych ugrupowaniach i SMC. Na trzy

\footnotetext{
${ }^{2}$ Ustawa podaje maksymalną wysokość wydatków (4000 płac minimalnych, około $16 \mathrm{mln}$ hrywien), które SMC może przeznaczyć na realizację kampanii wyborczej. W rzeczywistości w raportach finansowych SMC (liderów list) figurują łączne wydatki na kampanię wyborczą między 400-800 tys. hrywien.
} 
tygodnie przed wyborami kampania wyborcza była już bardzo widoczna nie tylko w centrum regionu - Mikołajowie, ale również w innych miastach obwodu Woznesensku, Pierwomajsku, Basztance, Oczakowie. Głównymi nośnikami reklamy outdoorowej były bilbordy (również przy głównych trasach obwodu), citylights (wyłącznie miasta) oraz namioty (miasta i miejscowości), gdzie były rozdawane materiały agitacyjne. Trudno nie zauważyć gigantycznych nakładów finansowych mających swoje oddzwierciedlenie np. w liczbie bilbordów czynnych parlamentarzystów ubiegających się o kolejną kadencję. Blogerka lokalnego portalu informacyjnego news.pn Elena Bereżnaja podała dane, według których obecni parlamentarzyści ubiegajacy się o reelekcję i zarabiający oficjalnie około 40 tys. hrywien wynajmują po około 200 bilbordów, z których każdy kosztuje między 5000-12000 hrywien za miesiąc ekspozycji. Stąd zasadne jest pytanie, skąd biorą pieniądze na kampanijne koszty, a raczej kto ich sponsoruje i co będzie chciał za to w przyszłości, po ich ewentualnym zwycięstwie.

Kandydaci stosowali cały wachlarz tradycyjnych technik dotarcia do wyborców, takich jak uściskdłoni na ulicy czy wizyty w mieszkaniach, ale w ich kampaniach brakowało wyjątkowości. Z wywiadów LTO 26 przeprowadzonych z SMC wynika, że zdecydowana większość z nich nie miała takich kampanijnych atrybutów jak chwytliwe hasło wyborcze, ciekawy znak rozpoznawczy, czy oryginalny program wyborczy. Główny przekaz do wyborców sprowadzał się do starych haseł: chęci walki z korupcją, zmianą starego establishmentu politycznego, wprowadzeniem Ukrainy do NATO i UE, obniżeniem taryf na usługi komunalne. Z wyjątkiem Ihora Kopytina (Sługa Ludu), startującego w DEC 129, nikt nie przyznał się do korzystania z usług profesjonalnego doradcy ds. wizerunku, który poprowadziłby kampanię. Administracje większych miast wydzieliły tablice, na których kandydaci mogli bezpłatnie prezentować swoje plakaty wyborcze. W Mikołajowie LTO 26 zlokalizował trzy takie miejsca, w stosunkowo atrakcyjnych lokalizacjach, jednak nic nie było na nich eksponowane - zostały puste. Nieodzownym elementem kampanii wyborczej na Ukrainie były masowe spotkania z wyborcami, najczęściej w formie koncertów w plenerze przestrzeni miejskiej. Specyfiką takich wydarzeń w obwodzie mikołajowskim była ich organizacja przy okazji np: Dnia Młodzieży, Dnia Stoczniowca, czy Dnia Marynarza. Podczas takich plenerowych eventów profesjonalni prowadzący angażowali mieszkańców do brania udziału w konkursach na scenie, w których do wygrania były czasem cenne nagrody. Wśród zebranych pod sceną aktywiści reprezenujący SMC rozdawali materiały agitacyjne, a dla dzieci były zorganizowane osobne atrakcje w postaci np. zabawy z clownem czy częstowanie lodami. Wydarzenia te oczywiście były zlokalizowane w okręgu, z którego startował SMC do parlamentu, ale na ten rodzaj kampanii pozwalali sobie tylko nieliczni - majętni kandydaci. Co ciekawe, SMC najczęściej pojawiał się na scenie góra dwa razy podczas całego eventu (z reguły na rozdanie nagród) i przemawiał nie dłużej niż minu- 
tę, np. składał życzenia obecnym, chwalił dzieci, życzył zdrowia i udanego wieczoru, po czym zapraszał do wysłuchania koncertu.

W przemówieniach brakowało stricte politycznego przekazu, czy choćby zaproszenia do wzięcia udziału w wyborach. Ciekawą odmianą był przyjazd do Mikołajowa lidera partii Gołos - Swiatosława Wakarczuka, który na mityngu ulicznym $\mathrm{w}$ centrum miasta wygłosił 40-minutowe przemówienie, w którym przyszłości Mikołajowa, jak i innych miast Ukrainy, upatrywał w rozwoju małego i średniego biznesu. Imprezy nie były wyjątkowo ochraniane przez policję, a atmosfera była bardzo przyjazna ${ }^{3}$.

Warto nadmienić, że żaden $\mathrm{z}$ wygranych $\mathrm{w}$ obwodzie mikołajowskim SMC (wszyscy partia Sługa Ludu) nie zdecydował się jednak na duże plenerowe eventy. W tym miejscu zasadne jest również pytanie o to, czy SMC sponsorujący nagrody dla młodych wykonawców może być posądzony o przekupstwo, tak samo jak inny kandydat, który rozdaje lody podczas własnego koncertu, którego jest organizatorem. Kwestią dyskusyjną jest, czy podczas imprez organizowanych przez miejską bądź obwodową administrację SMC biorący udział w kampanii powienien w ogóle występować na scenie, nie narażając się na zarzut o prowadzenie kampanii wyborczej ${ }^{4}$.

\section{NARUSZENIA KAMPANII WYBORCZEJ}

Według informacji upublicznionych przez mikołajowską obwodową policję w trakcie kampanii wyborczej (stan na 16.07.) wpłynęły 137 powiadomienia o naruszeniu prawa związanego z wyborami. Zdecydowana większość z nich (37 postępowań) dotyczyła prezentacji drukowanych agitacyjnych materiałów bez zamieszczenia zapisu o zamawiającym, nakładzie bądź identyfikacji drukarni, co jest sprzeczne z zapisami kodeksu administracyjnego Ukrainy $^{5}$. LTO 26 wielokrotnie zaobserwował na terenie AoR billbordy nieposia-

\footnotetext{
3 Napiętą atmosferę dało się odczuć jedynie 12 lipca podczas muzycznej imprezy zorganizowanej na ulicy Sobornej (centrum Mikołajowa) przez SMC Maksym Newenczanego DEC 129 (Opozycyjna Platforma - Za Życie). Imprezę ochraniała kilkunastoosobowa grupa policjantów i równie liczna grupa młodych wysportowanych mężczyzn, która wyprowadzała z thumu pijanych. Może to mieć związek z otwarcie prorosyjskimi kursem OPZŻ.

${ }^{4} 23$ czerwca podczas Dnia Młodzieży SMC i jednocześnie czynny poseł - Borys Kozyr zapowiedziany przez mera Mikołajowa wręczył na scenie nagrodę w wysokości 5 tys. hrywien zwycięzcy konkursu break dance. Koncert lokalnej grupy, której występ wieńczył imprezę również był sponsorowany przez Kozyra, choć, jak zaznaczali organizatorzy, decyzję o wsparciu finansowym i zamówieniu zespołu Kozyr podjął jeszcze w kwietniu (przed kampanią).

${ }^{5}$ https://mk.npu.gov.ua/news/vibori-2019/v-umovax-emoczijnoji-naprugi-zavershalnogoeta pu-viborchoji-kampaniji-pravooxoronna-sistema-maje-buti-oseredkom-nadijnostita-stabilnostiIvan-varchenko/
} 
dające „danych kontaktowych”. W opinii LTO 26 ten proceder ma na celu ukrycie kosztów poniesionych na kampanię, które powinny zostać ujęte w sprawozdaniach finansowych SMC czy partii.

Najbardziej namacalnym wizualnie łamaniem prawa wyborczego było niszczenie bilbordów poprzez strzelanie weń z paintballa kulkami z farbą. Mimo że było to dosyć powszechne zjawisko, ograniczyło się wyłącznie do niszczenia reklam konkretnych SMC i konkretnych partii politycznych ${ }^{6}$. Co ciekawe, powyższe przestępstwa nie były zgłaszane organom. Tylko Oleksandr Żołobecky DEC 129 poinformował LTO 26 o uszkodzeniu trzech z 65 własnych bilbordów, lecz odpowiedniego zawiadomienia na policję nie złożył.

Proces rejestracji został zgodnie oceniony przez SMDC jako przejrzysty i zrozumiały, co stanowi krok naprzód w stosunku do poprzednich kampanii. Czarny PR był stosowany wyłącznie w mediach społecznościowych, które były najpopularniejszą platformą prowadzenia kampanii wyborczej. Zdarzało się, że podczas spotkania któregoś z SMC z wyborcami organizowanymi np. w domu kultury nagle pojawiał się tam inny kandydat bądź jego zwolennicy, którzy przeszkadzali w spotkaniu, zadając np. tendencyjne pytania czy negatywnie oceniając kandydata ${ }^{7}$. LTO 26 był świadkiem takiej sytuacji podczas spotkania SMC Andrija Wadaturskiego DEC 130 we wsi Sofijiwka, kiedy przybyli z Odessy ludzie (określeni przez Wadaturskiego jako reprezentanci jego politycznego rywala) zdominowali w dużej części mityng, zarzucając mu bezsens budowy basenu w Basztance, za którą ten lobbował.

\section{ORGANIZACJE „CHARYTATYWNE”}

Powszechną praktyką stosowaną przez kandydatów było tworzenie przez nich organizaji pozarządowych (NGO), które w zdecydowanej większości funkcjonowały wyłącznie do okresu rejestracji SMC przez CEC i legalnego rozpoczęcia kampanii. Jest to po prostu możliwość ropoczęcia kampanii wyborczej wcześniej, niż sankcjonuje to prawo. Powyższe organizacje na ogół używają tych samych kolorów i haseł, które zostaną później użyte w rzeczywistej kapanii wyborczej. Co więcej ,aktywiści/sztab” takiej organizacji to te same osoby, które później poprowadzą rzeczywistą kampanię kandydata. LTO 26 zlokalizowało kilka tego rodzaju fundacji: „Z dobrem do ludzi” powiązana

\footnotetext{
${ }^{6}$ Borys Kozyr, Artem Iliuk, Maksym Newenczanyj, Oleksandr Żołobeckyj, Ihor Diatłow oraz partie OPZŻ, Europejska Solidarność

${ }^{7}$ Maksym Newenczanyj DEC 129 poinformował LTO $26 \mathrm{w}$ rozmowie telefonicznej, że jego spotkanie wyborcze we wsi Horychiwka w miejscowym domu kultury zostało zakłócone przez kontrkandydata - Serhija Krasiwskiego (Agrarna Partia Ukrainy), który stwierdził, że to on ma tu teraz spotkanie i zaczął dzielić salę na stronników Newenczanego i własnych.
} 
z Oleksanderem Żołobeckim (DEC 129), „Kroczymy z troską” - Ihor Bryczenko (DEC 130), „Sroka” - Natalia Sablina (DEC 132), „Szkoła Liderów” - Olha Pokrowska (DEC 127), „Centrum Pomocy Ihora Pawłowa” - Ihor Pawłow (DEC 127 ). W tym miejscu należy wspomnieć, że takie podmioty prawne kamuflują wydatki związane $\mathrm{z}$ docelową kampanią wyborczą na poczet swojej działalności charytatywnej.

Pozytywnym aspektem w tym mało przejrzystym obszarze było zwrócenie się przez przedstawicieli pierwszych trzech wymienionych powyżej NGO do szefa OPORY w Mikołajowie - Oleksandra Basztawowego celem wyjaśnienia, jak oddzielić dotychczasową działalność charytatwyną od kampanii wyborczej.

\section{OSOBLIWOŚCI KAMPANII}

Rozmówcy LTO 26 w AoR wielokrotnie reklamowali, że jednym z największych wyzwań mogą być te związane z masowym przekupywaniem wyborców przez SMC. W tym miejscu należy zaznaczyć, iż śledząc raporty międzynarodowych i ukraińskich organizacji obserwujących można odnieść wrażenie, że ten aspekt ostatni raz, na masową skalę, był stosowany podczas wyborów parlamentarnych w 2012 roku. LTO 26 podczas realizacji obserwacji wielokrotnie słyszał o pogłoskach dotyczących tego procederu, ale rozmówcy nigdy nie skonkretyzowali: kto, kiedy, gdzie i za ile.

Innym wyzwaniem jest sytuacja związana z pojęciem adminresursu, czyli wsparcia SMC bądź partii politycznej, udzielana przez lokalną bądź centralną administrację. $Z$ reguły rzeczony SMC najczęściej piastuje stanowiska w tejże administracji publicznej. Wsparcie ma polegać na zwiększonej promocji w mediach rzeczywistych bądź przedstawienia fikcyjnych osiąnięć konkretnego kandydata dla regionu. W praktyce bardzo trudno to udowodnić. Międzynarodowe standardy są precyzyjne - czynny urzędnik może realizować swoją kampaię wyborczą po zakończeniu godzin pracy. Dobrą praktyką w tej kwestii jest urlop na czas kampanii wyborczej. W celu promocji SMC uciekali się czasem do publikacji na swoich profilach społecznościowych (głównej trybuny prowadzenia kampanii wyborczej) kontrowersyjnych filmików ${ }^{8}$.

\footnotetext{
${ }^{8}$ Artem Iliuk DEC (niezależny) 128 kopnięciem otwierał butelkę, https://shipovn ik.ua/novo sti/sbej-kryshku-nogoj:-ilyuk-prinyal-uchastie-v-populyarnom-chellendzhe; Ihor Negulewskyj DEC 130 (Sługa Ludu) zwizualizował zakończenie kadencji WR, rozpędzając stado baranów, https://www.youtube.com/ watch?v=XQ7 Ydi5fs7I; Oleksandr Gajdu (Sługa Ludu) DEC 128 strzelał z karabinu maszynowego i strzelby do celów imitujących korupcję, https://www.youtube. com/watch?v=AC SgssEvEjM.
} 


\section{ŻONGLERKA BARWAMI KAMPANIJNYMI}

Powszechnym zjawiskiem stosowanym przez SMC było podszywanie się pod partię Sługa Ludu. Wielu kandydatów wykorzystywało jej barwy (żółć i zieleń) - Borys Kozyr, Artem Iliuk - aby wzmocnić swoje szanse na zwycięstwo. Jeden z SMC - Iwan Aleksiejenko DEC 127 - nazwał swoją firmę Sługa Ludu i oczywiście użył w swoich materiałach agitacyjnych kolorów żółtego i zielonego. Podobnie uczynił Walerij Koczmar DEC 129, który w swoim krótkim biogramie, zamieszczonym na portalu CEC, figurował jako założyciel Organizacji Społecznej - Sługa Ludu. Podobne kontrowersje dotyczą partii Opozycyjny Blok i Opozycyjnej Platformy - Za Życie (OPZŻ) $)^{9}$. Oba ugrupowania (wywodzące się z z OP) używały tych samych barw kampanijnych (kolory biały i niebieski) oraz tej samej stylistyki graficznej.

\section{TELEDEBATY}

Mikołajowski oddział państwowej Teledariokompanii UA (Suspilne telebaczenja) między 3 a 19 lipca wyemitował cykl debat telewizyjnych pod nazwą „Okręg wyborczy: debata”. Ideą projektu emitowanego „na żywo” było zapoznanie wyborcy z SMC z obwodu mikołajewskiego. Co ciekawe, w 15 odcinkach na 88 kandydatów w studiu łącznie pojawiło się jedynie 27. Program składał się z kilku części, a nad porządkiem czuwał prowadzący i ekspert. Jednorazowo udział w nim mogło brać maksymalnie sześć SMC z konkretnego okręgu, zapraszanych według kolejności alfabetycznej z listy wyborczej. Po pierwszych emisjach cyklu wyszło na jaw, że kandydaci mają problemy z rozpoznaniem tez z własnego programu wyborczego i nie znają treści ustawy Pro narodnych deputatiw Ukrainy. Oglądajac kolejne odcinki trudno było wskazać jakieś istotne różnice między prezentującymi się w nim kandydatami. Dało to do myślenia kolejnym uczestnikom, którzy się po prostu nie pojawili, gdy przyszła ich pora. Z DEC 132 (31 SMC) nie pojawił się nikt! To tylko potwierdza odczucie LTO 26, że SMC czują się dobrze tylko „na swoich warunkach” w gronie „własnego” elektoratu, bo jak inaczej wythumaczyć niewykorzystanie darmowej możliwości autoprezentacji w, bądź co

\footnotetext{
${ }^{9}$ W 2018 r. grupa polityków zgrupowana wokół Jurija Bojki, Witkora Medwedczuka i Wadyma Rabynowycza opuściła OP I utowrzyła OPZŻ. W zgodnej opinii komentatorów było to spowodowane brakiem akceptacji pozostałych - m.in. Ewgenija Murajewa, Oleksandra Wiłkuła, Genadija Kernesa na radykalnie prorosyjski kurs stronników Bojki. Nie bez znaczenia jest fakt utraty przez Platformę kluczowego sponsora - najbogatszego Ukraińca - Renata Achmetowa, który stracił dużą część swoich aktywów i pasywów na terytoriach okupowanych przez Rosjan i separatysów.
} 
bądź, telewizji o regionlanym znaczeniu, którą oglądają potencjalni wyborcy. Podczas spotkań z SMC LTO 26 zadawało pytanie o przyczynę ich nieobecności albo brak chęci wzięcia udziału. Dwie najpopularniejsze odpowiedzi to: „nie chcę brać udziału w prowokacji” i ,podczas nagrania miałem spotkanie z wyborcami, więc nie mogłem być". Do myślenia daje fakt, że z sześciu zwycięzców w obwodzie (wszyscy Sługa Ludu!) tylko Ihor Kopytin DEC 129 wziął udział w teledebacie.

Analogiczna sytuacja zaistniała $\mathrm{w}$ realizacji projektu otwartego czasu antenowego dla partii politycznych i SMC. W tym celu DEC 128 zorganizował publiczne losowanie terminu jednorazowej 20-minutowej filmowej prezentacji programu wyborczego SMC lub ugrupowań emitowanych również w kanale UA Mikołajów ${ }^{10}$. Według redaktora Oleksandra Rubana odpowiedzialnego zaprojekt ze strony stacji tylko $60 \%$ uprawionych z obwodu mikołajewskiego zarejestrowało bądź udostępniło wystąpienie, które potem zostało wyemitowane. Taka postawa wiele mówi o „charyzmie” i profesjonalizmie kandydatów i partii politycznych. Trudno sobie wyobrazić analogiczną sytuację w krajach Europy Środkowej, nie mówiąc o Europie Zachodniej, gdzie SMC nie przepuszczą żadnej okazji w dotarciu do potencjalnego wyborcy ze swoim przekazem.

\section{TRAGICZNE WYDARZENIE}

Na tydzień przed wyborami SMC Wasylij Mosjakyn (OP) DEC 132 z Pierwomajska popełnił samobójstwo, strzelając sobie ze strzelby w klatkę piersiową. Według wstępnych ustaleń policji nie stwierdzono udziału osób trzecich. Przed tragiczną śmiercią LTO 26 spotkał się w Pierwomajsku z Mosjakynem, który specjalnie na spotkanie przyjechał do nas do hotelu w celu udzielenia wywiadu. Podczas rozmowy nie sprawiał wrażenia osoby, która chcę się rozstać ze światem, był pogodny i skoncetrowany na swoich działaniach związanych z wyborami.

\section{ADMINISTRACJA WYBORCZA W OBWODZIE MIKOŁAJOWSKIM}

Naczelną instytucją odpowiedzialną za przeprowadzenie wyborów na Ukrainie jest Centralna Komisja Wyborcza (CEC - Central Election Commission) - to do jej kompetencji należy m.in. akceptacja wykonawczych stanowisk DEC

${ }^{10}$ Lokalne ośrodki telewizji państwowej mają ustawowy obowiązek realizacji takiego projektu. 
- szefa, zastępcy szefa oraz sekretarza, którzy kierują ich pracą ${ }^{11}$. W 6 DEC w AoR LTO 26 w zależności od komisji zasiadało od 16 do 18 osób. Prawo stanowi, że w pierwszej kolejności są nominowani z sześciu frakcji parlamentarnych zasiadających $\mathrm{w}$ parlamencie, w drugiej kolejności zaś od 29 partii, które wzięły udział w poprzednich wyborach parlamentarnych w 2014 roku.

Komisje obwodowe (Precinct Election Commissions - PEC) ${ }^{12} \mathrm{w}$ zależności od liczby wyborców w swoim obwodzie wyborczym posiadały liczbę członków komisji wahającą się między 12 a 18 . Ale to właśnie DEC pełnią strategiczną rolę $\mathrm{w}$ wyborach ${ }^{13}$. Poza krótkimi terminami ujętymi w kalendarzu wyborczym największym problemem w funkcjonowaniach komisji były permanentne zmiany składów komisji ${ }^{14}$. Pomimo relatywnie krótkiego terminu na przygotowanie się do przedterminowych wyborów można ocenić pracę DEC i PEC jak dobrą. Członkowie tych komisji zmierzyli się przede wszystkim ze wspomnianym negatywnym procederem odwoływania członków tychże komisji przez partie oraz kandydatów, którzy ich nominowali, co znacznie utrudniło ich prace, zwłaszcza w przededniu wyborów. Zdarzały się zmiany w samych kierownictwach. Warto dodać, że pora urlopowa nie sprzyjała naborowi członków komisji PEC, gdyż wielu z nich odpoczywało bądź pracowało w rolnictwie. Skutkowało to ilościowo minimalnym składem koniecznym do rozpoczęcia prac. Kierownictwo DEC było zmuszone korzystać z konieczności nominowania wymaganych członków własną decyzją administracyjną. Powszechną praktyką w tej kwestii było „obdzwanianie” znajomych w poszukiwaniu chętnych ${ }^{15}$. Gdy i to nie pomogło, szefostwo DEC 128 posunęło się do śmiałej inicjatywy ogłoszenia w lokalnej telewizji naboru do komisji PEC.

W tym miejscu trudno zrozumieć postawę niektórych partii czy SMC, którzy nie nominowali członków do prac w komisjach, natomiast obsadzili je

${ }^{11}$ Zgodnie z prawem na Ukrainie funkcjonują $225 \mathrm{DEC}$, ale z racji rosyjsko-separatystycznej okupacji Krymu oraz części obwodów donieckiego i ługańskiego sformowano wyłącznie 199 DEC, których mieszkańcy wybiorą 199 SMC. Tak więc w parlamencie ukraińskim 9. kadencji zasiądzie 424 posłów (225 z okręgu wielomandatowego, a 199 z okręgów jednomandatowych (DEC).

${ }^{12} \mathrm{~W}$ AoR LTO 26 funkcjonowały 924 PEC

${ }^{13}$ Do zadań DEC należy m.in.: organizacja sformowania komisji PEC, współorganizujacja szkolenia ich członków, dystrybucja pieczęci i dokumentacji wyborczej (w tym karty do głosowania), sprawowanie nadzoru merytorycznego nad działaniami PEC, gromadzenie dokumentacji wyborczej z PEC po głosowaniu, wprowadzanie danych z protokołów do systemu elektronicznego WYBORY, analiza raportów finansowych SMC, organizacja losowania darmowego czasu antenowego.

${ }^{14}$ Potencjalnie innym haniebnym procederem mogło być handlowanie kwotami - przydziałami członków komisji z różnych partii w istocie zabezpieczającymi interesy innej partii. LTO 26 nie udało się pozyskać informacji o występowaniu tego negatywnego zjawisku w AoR.

${ }^{15}$ Członkowie komisji DEC 130 (Basztanka), aby zebrać 124 osoby wymagane do zebrania minimalnej liczby członków PEC, wedle słów jej szefowej, wykonali około 1500 telefonów. 
obserwatorami zabezpieczającymi wyłącznie ich interesy, co tylko potwierdza instrumentalne podejście do kwestii wyborów. W związku z ograniczonym czasem i środkami finansowymi dochodziło do kuriozalnych sytuacji, jak w DEC 127, gdy tamtejsza szefowa DEC, w obecności LTO 26, zaproponowała jednemu z SMC (Władysław Jentin), który obserwował przebieg posiedzenia, aby ten rozwiózł po okręgu, w którym startuje, plakaty wyborcze z informacją wyborczą i wizerunkiem SMC startujących w wyborach. Wtedy Jentin odpowiedział: „Poproś Pasicznego (SMC, Sługa Ludu), on ma własną drużynę piłkarską".

Z kolei śmierć SMC Mosjakina stworzyła problem natury technicznej, ponieważ ten zmarł po oddaniu do druku kart do głosowania i jego nazwisko wciąż tam figurowało. Po długim milczeniu CEC podjęła decyzję o wykreśleniu jego nazwiska poprzez przekreślanie go pieczęcią ,usunięty”, co nie do końca współgrało z sytuacją. Sęk w tym, że pieczęci były wadliwie wykonane i przy takiej liczbie „odbić” zwyczajnie się psuły. Ostatecznie zostały zamienione na bardziej trwałe i ukończono przekreślanie nazwiska Mosljakina w ostatnim momencie przed wyborami.

\section{TRENINGI DLA DEC I PEC}

Zdecydowana większość komisji DEC i PEC podkreśliła zasadność szkoleń organizowanych dla nich przez autoryzowanych trenerów IFES/CEC, mających ich merytorycznie i praktycznie przygotować do przeprowadzenia procesu wyborczego. Wszyscy równocześnie podkreślili, że szkoleń powinno być więcej, a ilość materiałów do nauki zwiększona. W celu optymalizacji kosztów organizowano wspólne szkolenia (np. DEC 128 i DEC 130) w budynku należącym do DEC.

Pewną nowością była organizacja szkoleń dla PEC (trwała cztery godziny) organizowana przez IFES/CEC, a nie jak dotychczas przez członków DEC. Sporą niedogodnością był brak mikrofonu oraz niewystarczająca ilość materiałów szkoleniowych, tym niemniej spotkanie było okraszone okazałymi prezentacjami multimedialnymi produkcji CEC.

Większość członków komisji DEC miała wcześniejsze doświadczenie (około $70 \%$ ) w pracach zespołu i szkolenie miało za zadanie jedynie uaktualnienie wiedzy poprzez przedstawienie nowych regulacji prawnych. W tym roku do takich należał obowiązek rejestracji zamówień na np. wyroby papiernicze czy kancelaryjne w systemie zamówień publicznych PROZORO, czego wcześniej nie było. Komisje zostały pouczone o możliwości uniknięcia tego uciążliwego obowiązku, jeżeli zamówienia będą kwotowo rozbijać na kilka 
mniejszych ${ }^{16}$. Przykładem zaradności było również zorganizowanie szkolenia dla komisji PEC z DEC 130 nie w siedzibie DEC - Basztance, lecz w Sniguriwce. Taka decyzja została umotywowana katastrofalnym stanem drogi do Basztanki i ograniczeniami związanymi z lokalem DEC (brak klimatyzacji i mała sala).

\section{SPRAWA WOZNESENSKA}

DEC 131 to jedyna komisja w AoR, która od początku została wytypowana przez LTO 26 jako mogąca mieć problemy w realizacji swoich statutowych działań. Przyczyną obaw była postawa zastępcy szefa komisji - Oleksandra Kicenko, który w poprzednich latach był jej szefem i który kompletnie zdominował jej prace. Należy zaznaczyć, że szefem DEC 131 był Iwan Aleksiejew, stosunkowo niedoświadczony (wcześniej pracował wyłącznie jako członek PEC) i młody człowiek. Podczas wizyty LTO 26 w siedzibie DEC zastępca nie pozwolił nikomu dojść do słowa i niepochlebnie wyrażał się o działaniach CEC, „krótkim” kalendarzu wyborczym, zbyt dużej liczby PEC (189), braku środków finansowych na działalność DEC i ukraińskich politykach (nawet partii, która go desygnowała do pracy w DEC). Późniejsze jego działania potwierdzily obawy LTO 26. Lokalny obserwator OPORY - Oleksandr Rewenko złożył skargę do Sądu Administracyjnego na działalność DEC 131 z powodu wprowadzenia zaproponowanego przez Kicenkę „porządku prowadzenia posiedzeń DEC131". Samozwańczy akt zakładał m.in. zakaz uczestnictwa obserwatorów i dziennikarzy w posiedzeniach, co jest złamaniem prawa i ograniczał czasowo wystąpienia jego członków do trzech minut. Zanim doszło do rozprawy w tej sprawie CEC skontaktowało się z Kicenką i wezwało do natychmiastowego zaprzestania realizacji „porządku”. Mimo wykonania polecenia sąd obciążył DEC 131 kosztem rozpatrzenia sprawy i ją oddalił. To nie koniec kontrowersji - podczas przyjmowania protokołów i dokumentacji wyborczej Kicenko działał praktycznie jako jednoosobowa komisja, a kartony z materiałami nie były nawet otwierane. Równocześnie warto nadmienić, że DEC 131 jako pierwszy zakończył pracę w AoR i przekazał dokumentację do CEC. Po wyjeździe STO okazało się, że CEC nie zaakceptowała końcowego raportu DEC 131 i zarządziła wprowadzenie korekt do protokołu. Mit nieomylnego Kicenki upadł.

\footnotetext{
${ }^{16}$ Prawo mówi o konieczności rejestracji przetargu w systemie PROZORO jeżeli ten opiewa na kwotę wyższą niż 50000 hrywien.
} 


\section{DZIEŃ WYBORÓW W OBWODZIE MIKOŁAJOWSKIM}

Dzień wyborów (21.07.) jak i noc wyborcza przebiegły bardzo spokojnie w AoR LTO 26.

Pomimo bardzo napiętego kalendarza wyborczego, DEC i PEC zostały utworzone na czas i w zdecydowanej większości poradziły sobie $\mathrm{z}$ wyzwaniami dnia i nocy wyborczej. Praktycznie nie odnotowano żadnych poważnych incydentów ani istotnych nieprawidłowości. Jedyne co mogło zwrócić uwagę to obecność bilbordów, które zgodnie z prawem powinny zostać usunięte jeszcze przed dniem ciszy wyborczej ${ }^{17}$. STO w AoR LTO 26 poinformowały, że PEC otworzyły się na czas, pracowały profesjonalnie i kolegialnie i wszyscy członkowie komisji byli obecni. Tylko kilka bardzo drobnych nieprawidłowości proceduralnych zostało zgłoszonych przez STO podczas otwarcia lokali wyborczych, a głosowanie zostało ocenione przez STO i obserwatorów ukraińskich, jako zasadniczo bezproblemowe. Jednakże liczenie głosów, wprowadzanie danych do protokołów i prawidłowe pakowanie dokumentacji wyborczej nadal stanowią wyzwanie.

Generalnie DEC wykazały sporą determinację, aby zastosować się do wszystkich procedur wymaganych przez prawo, cieszy też stosunkowo niewielka liczba PEC, w porównaniu $\mathrm{z}$ ubiegłymi wyborami, odesłana w noc wyborczą w celu dokonania poprawek. Dowodem na profesjonalne działanie DEC był brak skarg na ich działalność, w tym kluczowym okresie, złożonych do Obwodowego Sądu Administracyjnego, policji i samych DEC. Problemy pojawiły się później. Poza problematycznym DEC 131 inny - DEC 127 miał problemy z akceptacją protokołów z pięciu PEC, co spowodowało powtórne przeliczenie głosów z tych komisji w siedzibie DEC, co w rezultacie skutkowało ogłoszeniem wyników dopiero 27 lipca (sześć dni po wyborach). Winą za ten stan mikołajowscy dziennikarze i ukraińscy obserwatorzy obciążyli ciągłe zmiany w tej komisji, (stosunkowy) brak doświadczenia jej członków i konflikty natury charakterologicznej między nimi.

${ }^{17}$ STO informowały LTO 26 o obserwacji bilbordów Sługi Ludu (partii) i Sługi Ludu SMC w dzień wyborów i poprzedzający go dzień ciszy. Podobna sytuacja dotyczyła bilbordów zachęcających do głosowania „Za Sergijowycza”, czyli w domyśle na SMC Ihora Sergijowycza Diatłowa DEC127 (OP) - świadczy o tym ta sama kolorystyka i stylistyka bilbordów. 


\section{WYBRANE RELACJE STO Z OBSERWACJI W AOR LTO 26}

\section{STO 2606 Martin Schroeder \& Harry Edelman}

Do PEC (szkoła), w której obserwowaliśmy otwarcie komisji - posiedzenie rozpoczęło się planowo o 7:15. Dziwi jedynie, że mieli do niej dostęp pracownicy fizyczni szkoty, $w$ tym do miejsca posiedzenia komisji. Siła rzeczy przeszkadzali w jej pracach.

STO 2604 Łukasz Tomik \& Barbara Jackson-Mcintosh

Praca DEC131 w noc wyborcza to byto one man show. Oleksandr Kicenko (zastępca szefa komisji) siedziat na scenie i osobiście przyjmowat komisje PEC. Zaakceptowat wszystkie, $w$ większości bez otwierania pudet z dokumentacja. Mimo jednej z największych liczbt PEC na Ukrainie ukończyli prace jako pierwsi w obwodzie.

\section{STO 2608 Susan McMahon \& Hans Nareskog}

Po przybyciu do PEC, w której mieliśmy obserwować zamknięcie, liczenie głosów i opracowanie protokotu poinformowaliśmy zastęce szefa komisji, że niezależnie od etapu liczenia glosów będziemy musieli opuścić komisję o 23.30. Ten odpowiedziat, że zgodnie z prawem nikt $z$ obecnych przy zamknięciu komisji i liczeniu głosów nie może opuścić PEC przed opracowaniem protokolu końcowego. Na ewentualna zmianę decyzji zdecydowaliśmy się poczekać na zewnatrz PEC, bo naszym priorytetem, jako Team B, byla obserwacja DEC od 24.00. Niestety nie otrzymaliśmy zgody na powrót do PEC, więc pojechaliśmy prosto do DEC.

[LTO 26 po otrzymaniu informacji, że STO 26 czeka przed PEC na decyzję o tym, że będzie mogła obserwować jej prace do 23.30 skontaktował się szefem DEC 129 z prośbą o interwencję w tej sprawie - pomoc we wpłynięciu na decyzję. Bez powodzenia].

\section{REKOMENDACJE}

W celu osiągnięcia wyższego poziomu obserwacji EOM ODIHR/OSCE warto rozważyć następujące rozwiązania.

\section{Team C}

Zasadne jest wprowadzenie dodatkowej grupy STO - Team $\mathrm{C}^{18}$. Jej zadaniem będzie monitoring procesu elektronicznego wprowadzania wyników z protokołów (papierowych) przywiezionych z PEC do DEC (tabulation). Wyniki te pojawiają się w portalu CEC i rolą Team $\mathrm{C}$ będzie sprawdzenie, czy są zgodne $\mathrm{z}$ liczbami przedstawionymi w papierowych protokołach. Liczba

${ }^{18}$ Teams (grupy) A i B STO to dwuosobowe zespoły obserwatorów krótkoterminowych, które mają za zadanie obserwacje pracy PEC i DEC w dniu wyborów i nocy wyborczej oraz raportowanie LTO o swoich obserwacjach. 
Team C powinna być równa liczbie DEC. Do tego projektu poza STO z ramienia ODIHR będzie wymagana partycypacja akredytowanych przez ODIHR ukraińskich obserwatorów (np. OPORA, KWU) oraz lokalnych dziennikarzy, którzy prześlą fotografie papierowego protokołu z PEC do Teamu C, który zweryfikuje go z danymi wprowadzonymi do systemu elektronicznego (WYBORY SYSTEM) w DEC. W wariancie rezerwowym osobą przesyłającą fotografię protokołu może być członek PEC. Jeżeli liczby nie będą się zgadzać Team C zawiadomi o tym fakcie STO, który aktualnie pełni dyżur w DEC, w celu podjęcia weryfikacji/interwencji u szefa DEC. Ten projekt wymaga gigantycznej mobilizacji lokalnych obserwatorów (na Ukrainie jest około 33 tys. PECs) oraz odtajnienia informacji o lokalizacji ostatniego wizytowanego PEC, w którym STO będą obserwować podliczanie głosów ${ }^{19}$. Team C nie musi być fizycznie zlokalizoany w AoR - może pracować zdalnie z Kijowa bądź nawet Warszawy.

\section{Okres postelekcyjny}

Warto zastanowić się nad wprowadzeniem kilkuosobowego zespołu, który będzie monitorował przebieg procesów sądowych związanych z wyborami oraz przeanalizuje ostateczne raporty finansowe partii oraz SMC w okresie postelekcyjnym $^{20}$. Na przykład SMC Oleksandr Kusznir DEC 132 nie zapłacił aktywistom za ich pracę, co wywołało protesty. Obserwacje takiego zespołu posłużą w przyszłości (w kolejnych wyborach) jako baza wiedzy dla LTO.

\section{Język}

Możliwość używania przez LTO języka lokalnego ${ }^{21}$ w AoR jest zaletą. Posługiwanie się językiem urzędowym bądź powszechnie używanym w AoR skutkuje uzyskaniem co najmniej $30 \%$ więcej informacji niż posługiwanie się językiem angielskim (oficjalny język misji). Rozmówcy czują się znacznie bardziej komfortowo i są bardziej otwarci w kontakcie z LTO, jeżeli obserwator posługuje się ich językiem. To również podkreśla fakt nieprzypadkowości w wyborze obserwatora i jest ukłonem w stosunku do państwa przyjmującego. Jeżeli partner nie włada lokalnym językiem to asystent (integralna część zespołu LTO) przetłumaczy, co powiedział partner. Poza tym thumaczenie wszystkiego na język angielski znacznie wydłuża czas uzyskania informacji,

${ }^{19}$ Wybór PEC, w którym STO będą obserwować podliczanie głosów odbywa się poprzez losowanie. Nie może to być tzw. PEC specjalny jak szpital czy więzienie i nie powinien być ulokowany dalej od DEC niż 30 min podróży samochodem w przypadku grupy B i $60 \mathrm{~min}$. w przypadku grupy A.

20 Jest tajemnicą poliszynela, że spora część partii politycznych i SMC w ogóle nie sporządza ostatecznego protokołu z wydatków na kampanię do czego jest zobowiązana prawnie. Z kolei CEC, jak i ukraińskie społeczeństwo nie wykazują determinacji w monitoringu tej kwestii, która jest często kontrowersyjna (kto naprawdę finansuje kampanie wyborcze) i prezentuje postawę: „było, minęło...”.

${ }^{21} \mathrm{~W}$ tym przypadku języka ukraińskiego bądź rosyjskiego. 
a rozmowa po angielsku np. obserwatora z Polski i np. szefa DEC (Ukraina) nawet $\mathrm{z}$ thumaczeniem sprawia obojgu wręcz ból fizyczny i jest kuriozalna.

\section{Raportowanie}

Wybory na Ukrainie odbywają się stosunkowo często, a ODIHR/OSCE stale pełni przy nich misję obserwacyjną 22 . Należy więc wymagać od CT przewidzenia scenariuszy rozwoju sytuacji i dystrybucji już na pierwszym briefingu ${ }^{23}$ wszystkich arkuszy, które będą wymagały wypełnienia przez LTO oraz ich szczegółowego omówienia. Trzeba mieć świadomość, że ze względu na rozległy teren AoR nie będzie powtórnej możliwości spotkania z rozmówcą.

\section{„Papierologia”}

Trudno racjonalnie zrozumieć obowiązek wypełnienia przytłaczającej ilości dokumentów natury kadrowo-logistyczne ${ }^{24}$ przez LTO, szczególnie w sytuacji, w której okres od rozpoczęcia misji do wyborów to nie więcej niż pięć tygodni. Czasami wręcz trudno nie odnieść wrażenia, że CT przedkłada tego typu odtwórczą działalność nad osobisty kontakt z mieszkańcami AoR. Stąd propozycja, aby np. raport finansowy LTO sporządzało dwukrotnie - w połowie misji i pod koniec.

Dla porównania - inne międzynarodowe misje (np. Międzynarodowy Instytut Republikański) wymagają znacznie mniej dokumentów.

\section{REKOMENDACJE DLA UKRAINY}

\section{Deadline na zamianę czlonka DEC bądź PEC}

Należy wyznaczyć ostateczny deadline dla zamian członków komisji DEC i PEC przed wyborami, a szczególnie ich kierownictw (przewodniczący, wice-przewodniczący, sekretarz). To właśnie zamiany członków komisji są zmorą wszystkich wyborów na Ukrainie i generują chaos wyborczy. Zgodnie $\mathrm{z}$ prawem mogą je dokonywać partie polityczne nominujące członków PEC, SDMC oraz same komisje nawet w dzień wyborów. Po wyznaczonym deadlinie wycofanie członka komisji przez partię czy SMC może odbyć się tylko $\mathrm{z}$ istotnych przyczyn zdrowotnych. W przeciwnym razie groziłaby dotkliwa kara finansowa.

${ }^{22} \mathrm{Z}$ wyjątkiem obserwacji wyborów do gromad, których ODIHR/OBCE nie obserwuje.

${ }^{23}$ Konferencja dla LTO rozpoczynająca ich misje obserwacyjną.

${ }^{24}$ Do takich formularzy i dokumentów należą: kontrakt dla asystenta i tłumacza, ich czas pracy (nadgodziny), zużycie paliwa samochodu kierowcy, cotygodniowy (!) raport finansowy (szczególnie uciążliwy), obowiązek pisemnego informowania o planowanych wyjazdach w teren (poza siedzibę LTO), kwestie bezpieczeństwa. 


\section{Obowiązek nominacji do PEC przez SMC}

CEC powinna nałożyć na SMC obowiązek delegowania do komisji PEC w okręgu, w którym startuje co najmniej 30 członków. Odpowiedni zapis w ustawie Pro narodnych deputatiw Ukrainy znacznie ograniczy brak zagrożenia zerwania wyborów w określonych PEC na skutek niezebrania minimalnej liczba członków komisji. Zapis powinien precyzować, że członek nominowany przez SMC musi być obecny w pracach komisji PEC od momentu pierwszego posiedzenia komisji do momentu akceptacji protokołu i dokumentacji wyborczej ${ }^{25}$.

\section{Dwie komisje}

Warto rozważyć rozwiązanie wprowadzone w Polsce w wyborach samorządowych- funkcjonowanie kolejno po sobie dwóch komisji wyborczych w jednym PEC. Jedna odpowiada za otwarcie, głosowanie i jego zakończenie oraz sporządza z tego protokół. Potem następuje przekazanie dokumentacji wyborczej drugiej komisji, która odpowiada za podliczenie głosów, sporządzenie protokołu końcowego i dostarczenie go wraz z całą dokumentacją do DEC. Takie rozwiązanie ułatwia, przyspiesza i ogranicza pomyłki robione przez drugą komisję, która do pracy przystępuje wypoczęta.

\section{Walka z ,klonami”}

Zjawisko występowania klonów to smutna rzeczywistość ukraińskich wyborów ${ }^{26}$. Ograniczeniem tego procederu może okazać się obowiązek zebrania przez SMC podpisów poparcia kandydatury, jako jeden z warunków biernego prawa wyborczego. Taki manewr prawny znacznie utrudni rejestrację klonów i wyświetli ewentualnych organizatorów przekrętu, którzy będą lobbować wśród mieszkańców DEC za podpisem na fikcyjnego kandydata.

\footnotetext{
${ }^{25}$ Rzeczywistość ukraińska dowodzi, że w razie braku doprecyzowania absolutnie obowiązkowego terminu pracy członka komisji SMC będzie miał możliwość nominowania członka komisji, a potem jego odwołania.

${ }^{26}$ „Klon” to osoba, która ma takie samo nazwisko, a często również i imię jak rzeczywisty kandydat. Celem operacji rejestracji klona jest odebranie prawdziwemu kandydatowi głosów przez zdezorientowanego wyborcę, który najczęściej przez nieuwagę, oddaje swój głos na klona, gdyż ten jest wyżej w kolejności od góry na karcie do głosowania . Najczęściej klon nawet nie mieszka na terenie obwodu, w którym startuje. W okręgu 127 LTO26 zidentyfikowało dwóch klonów Ihora Diatłowa, którzy łącznie odebrali mu 2,02\% głosów.
} 


\section{STATYSTYKA WYBORCZA}

Frekwencja (okręg wielomandatowy) - 49,8\% (najniższa w historii wyborów parlamentarnych Ukrainy).

Frekwencja w obwodzie mikołajowskim - 47,09\%.

Pięcioprocentowy próg pokonało pięć partii (czcionka pogrubiona).

Ta b e l a 2. Statystka DEC i PEC

\begin{tabular}{|c|c|c|}
\hline DEC & PEC & Liczba wyborców \\
\hline 127 & 124 & 144635 \\
\hline $\mathbf{1 2 8}$ & $\mathbf{8 9}$ & $\mathbf{1 6 2 5 5 6}$ \\
\hline 129 & 105 & 144552 \\
\hline $\mathbf{1 3 0}$ & $\mathbf{2 3 3}$ & $\mathbf{1 3 7 6 9 2}$ \\
\hline 131 & 189 & 151976 \\
\hline $\mathbf{1 3 2}$ & $\mathbf{1 8 4}$ & $\mathbf{1 3 7 6 5 6}$ \\
\hline
\end{tabular}

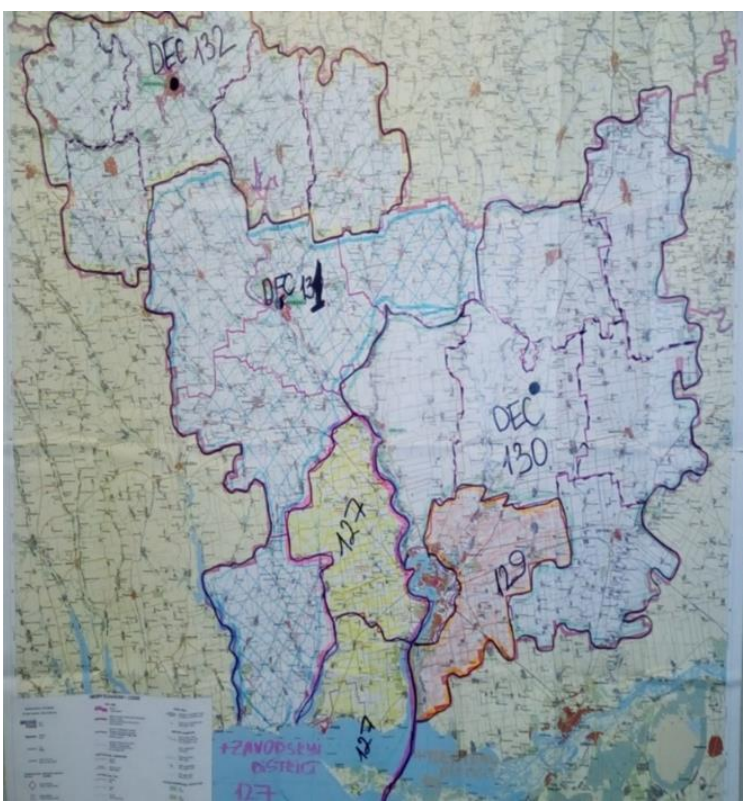

Rysunek 1. Podział AoR na DEC 